\title{
Influence of Geographical Conditions on the Spatial Structure of Jayapura City
}

\author{
Alfini Baharuddin ${ }^{1,2, *}$, B. Hari Wibisono ${ }^{2}$, Budi Prayitno ${ }^{2}$, and M. Sani Roychansyah ${ }^{2}$ \\ ${ }^{1}$ Department of Architecture and Planning Universitas Sains dan Teknologi Jayapura \\ ${ }^{2}$ Department of Architecture and Planning Universitas Gadjah Mada \\ *)Corresponding author (e-mail: alfinibaharuddin@yahoo.com)
}

\begin{abstract}
Jayapura City is situated on the eastern tip of Indonesia and borders the neighboring country Papua New Guinea (PNG). Its geographical conditions are very diverse dominated by hills leading to the formation of separated urban areas. Currently, there are two major urban areas, Jayapura and Abepura. Historically, Jayapura and Abepura were two old towns established in the Dutch rule, namely Hollandia Haven and Hollandia Binnen. They are detached by Skyline hills that hinder their complete physical merger. The presence of two separate urban areas in Jayapura City is also reinforced by the image perceived by the residents regarding with the powerful visual image of those cities. It, however, forms unique and distinctive properties in the spatial structure of Jayapura City. This study examines how the influence of geographical conditions on the spatial structure of Jayapura City. Data collection was done through direct observation and structured interviews with respondents of Jayapura and Abepura. Direct observation was conducted to obtain data on the use of land that forms patterns in Jayapura City area. While collecting data through questionnaires conducted to determine the image of residents of Jayapura City on the spatial structure of the city. The results showed that the geographical conditions in Jayapura City affect the formation of two separate parts of the city. The geographical condition is also an element forming a strong spatial structure as a characteristic reinforces the visual impression of the existence of two urban areas within Jayapura City. In its development, the existence of two urban areas show the persistent characteristics of 'two cities within a city'.
\end{abstract}

Keywords: geographical conditions, spatial structure, image, Jayapura City.

Abstrak. Kota Jayapura terletak di ujung timur Indonesia dan berbatasan langsung dengan negara tetangga, Papua New Guinea (PNG). Kondisi geografis Kota Jayapura yang sangat beragam yang didominasi oleh perbukitan mengakibatkan terbentuknya wilayah kota yang terpisah-pisah. Saat ini terdapat dua bagian besar wilayah kota yang dikenal dengan sebutan Jayapura dan Abepura. Secara historis, Jayapura dan Abepura dahulu merupakan dua kota lama yaitu Hollandia Haven dan Hollandia Binnen. Kedua area kekotaan ini dipisahkan oleh perbukitan Skyline sehingga tidak memungkinkan terjadinya peleburan batas-batas kedua wilayah kota tersebut. Terdapatnya dua kota yang terpisah di dalam Kota Jayapura juga diperkuat dengan image warga masyarakat yang masih mempunyai kesan visual yang kuat terhadap keberadaan dua kota tersebut. Kondisi ini memunculkan karakter yang unik dalam struktur keruangan Kota Jayapura. Penelitian ini mengkaji bagaimana pengaruh kondisi geografis terhadap struktur keruangan Kota Jayapura. Pengumpulan data penelitian dilakukan melalui pengamatan langsung dan wawancara terhadap responden Jayapura dan Abepura. Pengamatan langsung dilakukan untuk memperoleh data mengenai penggunaan lahan yang membentuk pola-pola lahan terbangun di Kota Jayapura. Sedangkan pengumpulan data melalui kuesioner dilakukan untuk mengetahui image warga Kota Jayapura terhadap struktur keruangan kota Hasil penelitian menunjukkan bahwa kondisi geografis di Kota Jayapura mengakibatkan terbentuknya dua bagian wilayah kota yang terpisah. Kondisi geografis ini juga merupakan elemen pembentuk struktur keruangan yang kuat sebagai ciri khas visual yang semakin memperkuat kesan adanya dua area perkotaan di dalam Kota Jayapura. Dalam perkembangannya, keberadaan kedua area perkotaan menunjukkan karakteristik yang tetap bertahan yaitu adanya 'dua kota di dalam sebuah kota'.

Kata Kunci: kondisi geografis, struktur keruangan, image, Kota Jayapura. 


\section{Introduction}

Jayapura City is the provincial capital of Papua which is situated on the eastern tip of Republic of Indonesia and borders the nation of Papua New Guinea (PNG) to the east. It covers an area of $940 \mathrm{~km}^{2}$ comprising of 5 districts, namely North Jayapura of $5.43 \%$; South Jayapura of $4.62 \%$; Abepura of $16.56 \%$, Heram of $6.72 \%$; and Muara Tami of $66.67 \%$. Those districts comprise of 25 villages and 14 hamlets. Out of total area, around 53\% is inhabited as it consists of rough terrains, swamps, and protected forests (Bappeda Kota Jayapura, 2014). The diverse geographical conditions of Jayapura City form separated urban areas. Currently, the community of Jayapura recognizes the cities of Jayapura and Abepura, even though those two cities are located in the administrative region of Jayapura City. The center of Jayapura City is situated at Yos Sudarso Bay, while Abepura City is at Abepura Circle. Those two cities are detached by hills named Skyline.

The well-known two cities within Jayapura City, namely Jayapura and Abepura, are inevitably related to the history of Jayapura City. The area of Jayapura and Abepura was an old town center established during the reign of the Netherlands and the Allies at the beginning of the founding of Jayapura City. The area recently known as Jayapura was previously named after Hollandia Haven, while Abepura was called Hollandia Binnen. Hollandia Haven or 'Hollandia' was precisely in Yos Sudarso Bay, a narrow strip of land dominated by hills. Now, this area is the administrative region of North Jayapura and South Jayapura. It was the first area where Captain Sasche built the post of a military bivouac and proclaimed the establishment of Hollandia on March 9, 1910. In the meantime, Hollandia Binnen was situated in the hinterland of broader plain. It is currently the administrative region of Abepura District and Heram District. It was also the administrative center of Allied soldiers and later became the central Dutch government after the Second World War in 1946. However, The Dutch government moved the administrative center to Hollandia Haven in 1958 (Roscoe, 1959; Kambu, dkk., 2009).

Harshorne (1938) mentions the phenomenon of two cities which he calls as the model of Twin City District of Minneapolis-St. Paul, each lies on both sides of the Mississippi. St. Paul is the state capital of Minnesota (USA), while Minneapolis is the capital of Hennepin County and the largest city in Minnesota. Minneapolis and St. Paul has a distinctive cultural landscape of 'Twin City district', in which those cities are almost completely separated, not merely politically but geographically, and yet in close contact with each other along one common zone. The centers of those cities are interdependent despite several differences in cultural traits of each city. Hartshorne argues that the stability of twin city model is likely due to the geographical situation. The structure of the highway is a powerful factor of the stability and two commercial cores with rapid investment strengthened by psychological factors will tend to retain its unique geographical form of two cores in different areas.

Budapest, the capital of Hungary, is an example of the city previously consisted of two separate cities of Buda and Pest, each lie on both sides of the Danube. Buda was a hilly area located in the west of Danube, while Pest was a plain area situated in the east of Danube. Buda was the royal palace on the hill serving as the capital of Hungary. Later, Buda joined Pest which was dominant as the commercial and cultural center. The boundary between those two cities was replaced with bridges connecting them (Morris, 1971 in Hartshorn, 1992). Kostof (1992) also confirm Twin City as the city pair section which is connected in parallel, for example between the administrative capital with the military base. The link between the city pair section is the main road of military camp to the administrative capital.

In Indonesia, Bandar Lampung as the provincial capital of Lampung is one of the cities whose the formation process is almost similar with Budapest. It is the fusion of two cities of Teluk Betung and Tanjung Karang or well-known as Teluk Betung-Tanjung Karang before named after Bandar Lampung. Both cities were merged into one city, namely Bandar Lampung City, by omitting the indistinct boundaries of those two cities. Teluk Betung is located in adjacent to the Lampung Gulf and Tanjung Karang is situated in higher land in the northern part of Betung Gulf, with approximately $5 \mathrm{~km}$ in distance. The absence of a natural boundary between those cities makes there is a framework of the steady city line (Ministry of Internal Affairs, 2013).

Despite the fact that Jayapura City is historically formed from two old cities, the 
development of Jayapura City is distinguished from Budapest or Bandar Lampung. Nevertheless, both of Buda-Pest and Teluk Betung-Tanjung Karang were unified into a city by omitting the boundaries, while Jayapura City seems to maintain the dualism of the areas although Jayapura and Abepura have become an administrative area of Jayapura City. The presence of two geographically separated cities within Jayapura City presents the extraordinary character of Jayapura spatial structure attached to most of the visual impression. This study examines how the influence of geographical conditions on the spatial structure of Jayapura City.

The spatial structure shows the specified distinctive compositions of a space (Yunus, 2010). De Chiara and Koppelman (1996) suggest that the spatial structure is expressed as the physical planning and design of an open space at a site. Spatial structure is generally the result of distinctive topography as natural properties. While one of the non-natural properties is landuse. The characteristics of spatial landscape commonly rely on three points, namely, the area, the visual degree of enclosure visual, and the visual properties.

\section{Research Methods}

To assess the spatial structure of Jayapura City, the investigation on the natural and nonnatural properties that formed the city including topography and land-use as well as the visual impression of the people was carried out (De Chiara and Koppelman, 1996). The collection of data was derived from direct observation, secondary data collection, and structured inteview. Direct observation was performed to obtain the data on land-use shaping the constructed land pattern in Jayapura City. Secondary data was retrieved by collecting supporting data related to the spatial of Jayapura City. In addition, structured interview primary data was conducted through a questionnaire to find out the image of Jayapura City regarding with the spatial structure of Jayapura City. The respondents were the residents of Jayapura City who selected randomly. The amount of respondent can be determined using Slovin formula (in Sugiyono, 2011):

$$
n=\frac{N}{1+N \cdot e^{2}}
$$

Where:

$\mathrm{n}=$ total sample

$\mathrm{N}=$ population

$\mathrm{e}=$ margin of error, $\mathrm{e}=0,1$

This formula is used because in this study population size is measured, i.e. the population of Jayapura and Abepura in 2013, where the population of Jayapura is 140.277 inhabitants, and a population of Abepura is 130.298 inhabitants (BPS Jayapura City, 2014). Base on Slovin formula (in Sugiyono, 2011), the total minimum of Jayapura respondent must be taken is 110 respondents, and Abepura respondent is 110 respondents.

\section{Results And Discussion}

\section{a. The Influence of Geographical Condition on Spatial Physical Development}

Geographically, Jayapura City is dominated by hills that cause the majority of the land cannot be developed as cultivation area, while the land for cultivation area should be the dominant area. Land suitability of Jayapura City can be examined from the physical aspects, the spatial policy, and the carrying capacity of infrastructures. The area meets the requirement to be developed as cultivation area is 40,492 ha or $43 \%$ of the total area, while the non-suitable area is approximately 53,508 ha or $57 \%$. Suitable area for cultivation is located in Muara Tami District, which is $87 \%$ of the total suitable area for cultivation. North Jayapura District has the smallest for cultivation i.e. 60 ha where is South Jayapura District has 378 ha (Table 1).

Table 1. Land Suitability Area in Districts of Jayapura City

\begin{tabular}{llrlrlr}
\hline \multirow{2}{*}{ No. } & \multirow{2}{*}{ District } & \multicolumn{2}{c}{ Suitable } & \multicolumn{2}{c}{ Non Suitable } & \multirow{2}{*}{ Total (ha) } \\
\cline { 3 - 6 } & & Area (ha) & \multicolumn{1}{c}{$\%$} & Area (ha) & \multicolumn{1}{c}{$\%$} & \\
\hline 1. & North Jayapura & 60 & 1.18 & 5,040 & 98.82 & 5,100 \\
2. & South Jayapura & 378 & 8.71 & 3,962 & 91.29 & 4,340 \\
\hline 3. & Abepura & 3,274 & 21.03 & 12,296 & 78.97 & 15,570 \\
4. & Heram & 1,505 & 23.81 & 4,815 & 76.19 & 6,320 \\
\hline
\end{tabular}




\begin{tabular}{ccccccr}
\hline \multirow{2}{*}{ No. } & \multirow{2}{*}{ District } & \multicolumn{2}{c}{ Suitable } & \multicolumn{2}{c}{ Non Suitable } & \multirow{2}{*}{ Total (ha) } \\
\cline { 3 - 6 } & Area (ha) & $\%$ & Area (ha) & $\%$ & \\
\hline 5. & Muara Tami & 35,274 & 56.29 & 27,396 & 43.71 & 62,670 \\
\multirow{2}{*}{ Total (ha) } & 40,492 & 43.08 & 53,508 & 56.92 & 94,000 \\
\hline
\end{tabular}

Source: Bappeda Kota Jayapura, 2014 (Data analysis)

From the land positioning based on the assessment of the productive area in Jayapura City, the optimal land has been utilized for the urban productive area is at the northern part of Jayapura City. The areas developed as urban areas of Jayapura City include North Jayapura
District, South Jayapura District, Abepura District and Heram District. Nevertheless, the suitable area mostly located in Muara Tami District has not been optimized as urban area as it is dominated by agricultural land (Figure $1)$.

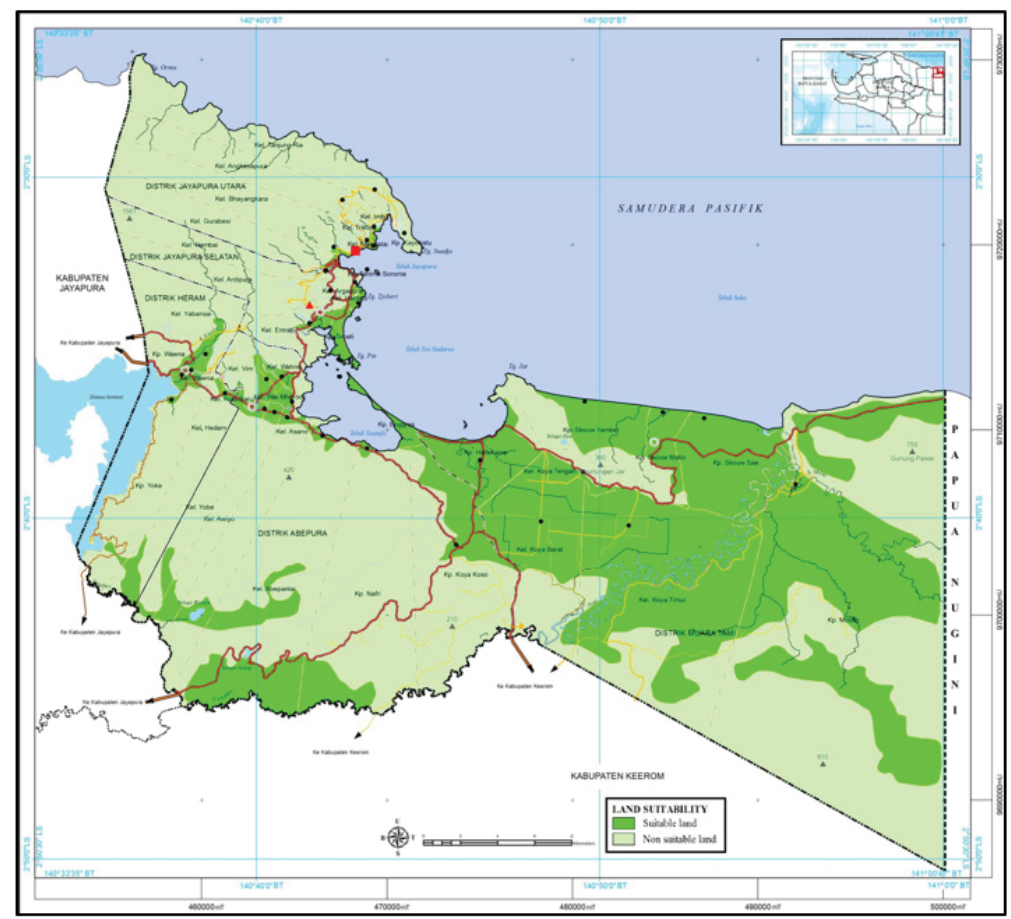

Source: Bappeda Kota Jayapura, 2014

Figure 1. Land Suitability Map of Jayapura City

The geographical conditions of Jayapura City lead to the development of the built-up area in fragmentary. From the assessment of the urban built-up area, there are two urban areas situated in the north and the south part (Figure 2 ). The urban areas in the northern part of the Jayapura City are North Jayapura and South Jayapura District, while the urban areas in the southern part of Jayapura City are Abepura District and Heram District. Nowadays, the residents of Jayapura City recognize Jayapura and Abepura within the city. Jayapura region covers North Jayapura and South Jayapura District, while Abepura region includes Heram District and Abepura District. Geographically,
Jayapura region is the northern part of the Jayapura City in adjacent to Yos Sudarso Bay with the domination of hilly geographical conditions. While Abepura region is the southern part of Jayapura City with broader plains than Jayapura region. Between Jayapura and Abepura, there are Skyline hills at a latitude of $200 \mathrm{~m}$ above sea level. Skyline hills are non-built-up area and it also covers Yotefa Park protected the forest. These conditions resulted in the built up areas of Jayapura and Abepura are separated by the non-built-up area of Skyline hills. However, they are connected by a primary arterial highway crossing Skyline hills of $3 \mathrm{~km}$ in length. 


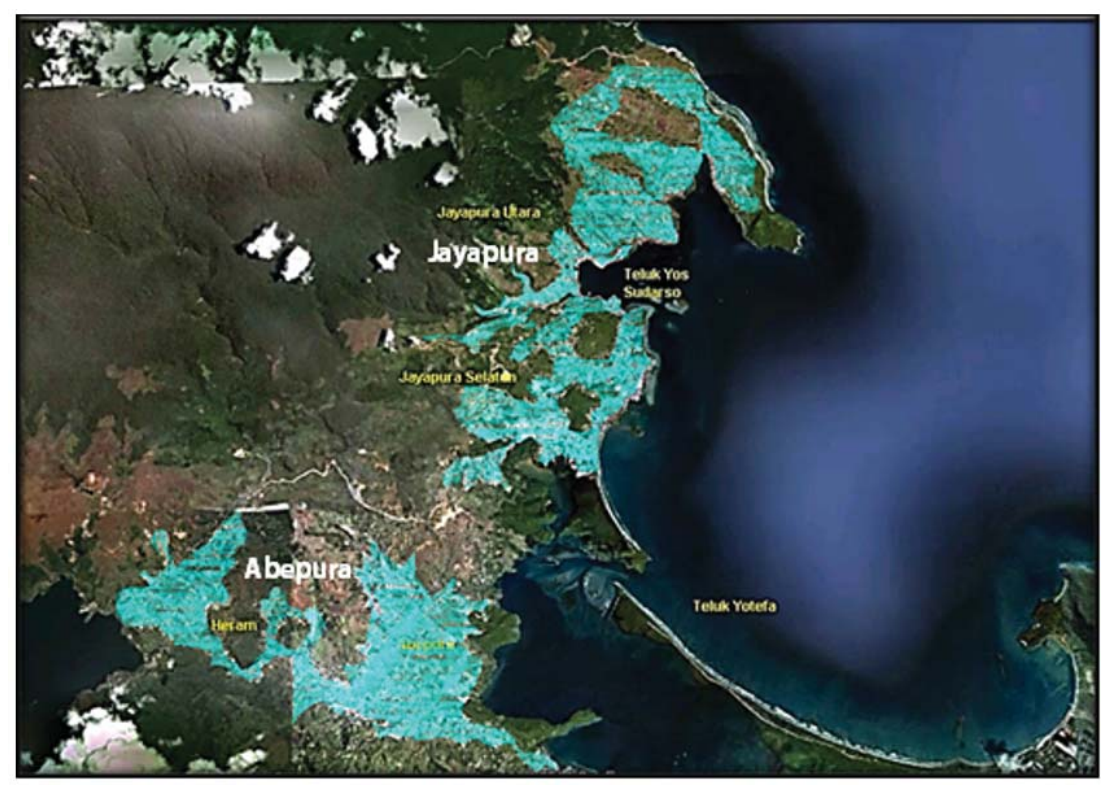

Source: Google Earth, 2013 (Data analysis)

Figure 2. The urban areas of Jayapura City

Jayapura area serves as the central government and the economy. Jayapura is situated on Yos Sudarso Bay has a port that serves as a major transportation node nationwide. As the center of economic activity, Jayapura is strongly supported by the activity at the Port of Jayapura with an important role in receiving various economic commodities from other regions and also distributes goods to destinations around Jayapura. Various facilities economy is growing rapidly in this area. Currently, developments in Jayapura tend to have saturated because the availability of suitable land is very limited because its topography is dominated by hills.

Abepura is located in hinterland area which serves as a center of growth and the economy. Abepura has a major role to the growth of the region around Jayapura City. Abepura also a transport node as a transit area on the main route leading to the buffer zones around Jayapura City which is the center of agricultural production. As a growth center, Abepura experiencing rapid economic development in terms of providing economic facilities are supported by the availability of suitable land is quite spacious compared to the Jayapura area.

\section{b. The Influence of Geographical Conditions on Residents' Visual Image}

The geographical conditions of Jayapura City prevailed by the hills/mountain in which the urban areas are constructed on each side of the hills/mountain brought a consequence of the designation of the strong spatial structure with the hill as urban spatial landscape (Figure 3). It is the particular characteristic of the spatial image which is able to affect person's interpretation or impression on a space in accordance with the attached visual image.

The existence of two urban areas in Jayapura City assessed from geography perspective was further analyzed by a survey on the image of Jayapura City regarding with the existence of those two urban areas by distributing a questionnaire to the residents of Jayapura City. It was carried out to eliminate the subjectivity of the observations. Survey was performed with 220 respondents as the participant consisting of 110 respondents from Jayapura and 110 respondents from Abepura. The result showed that $72,73 \%$ respondents from Jayapura assume that Jayapura and Abepura are two separate cities, meanwhile 27,27\% respondents have a contradictory opinion. In 
addition, as many as $74,55 \%$ respondents from Abepura consider that Jayapura and Abepura are two separate cities and $25,54 \%$ respondents think Jayapura and Abepura is one single city. Entirely, $73.64 \%$ respondents perceive Jayapura and Abepura are two different cities

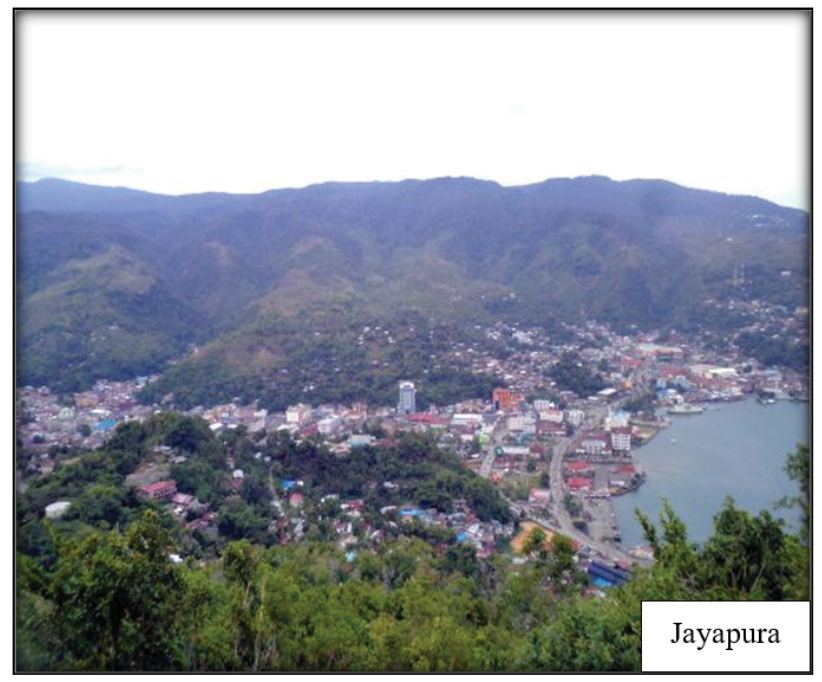

within Jayapura City and $26.36 \%$ respondents think that Jayapura and Abepura are nonseparated cities. It indicated that most of the residents of Jayapura City assume that Jayapura and Abepura are two separated cities within Jayapura City (Table 2).

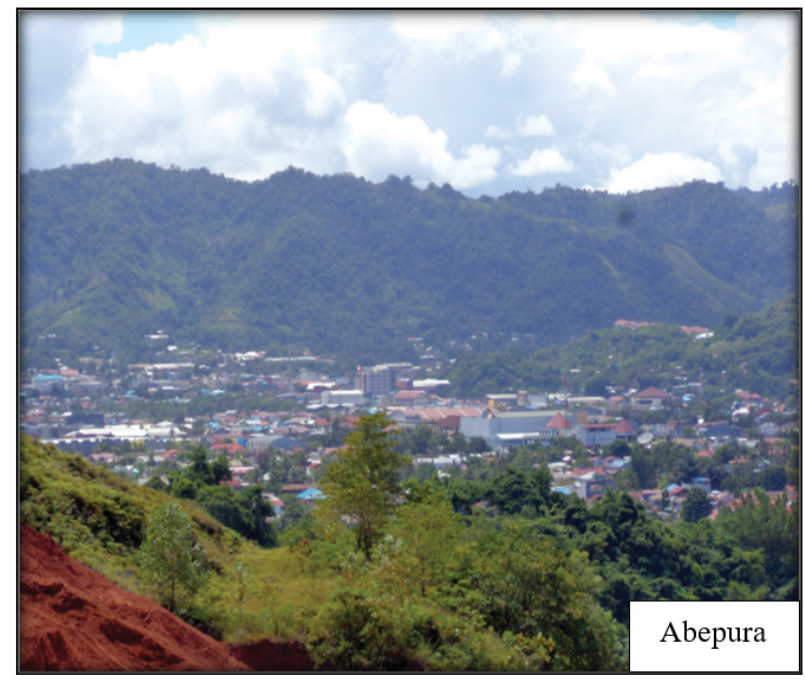

Figure 3. The hills shape a determined spatial structure as landscape element in urban areas of Jayapura City Source: Research survey, 2014

Table 2. The responses of the respondents on the existence of Jayapura and Abepura

\begin{tabular}{lccccc}
\hline & \multicolumn{5}{c}{ Image on the existence of two cities } \\
\cline { 2 - 5 } & Yes & $\%$ & No & $\%$ & Total \\
\hline Respondents of Jayapura & 80 & 72,73 & 30 & 27,27 & 110 \\
Respondents of Abepura & 82 & 74,55 & 28 & 25,45 & 110 \\
Total & 162 & 73,64 & 58 & 26,36 & 220 \\
\hline
\end{tabular}

Source: Research survey, 2014.

From the result of $73,64 \%$ respondents assuming that Jayapura and Abepura are two separated cities, there was a follow-up inquiry on the image of Jayapura and Abepura as two separate cities. The questionnaire on the image why Jayapura and Abepura seem to be two separated cities instead of one single city demonstrated that $47,53 \%$ respondents opt up Skyline hills as the reason; $22.22 \%$ respondents opt up the distance between those areas; $9.88 \%$ respondents opt up the availability of only one arterial highway between those areas; $7.41 \%$ respondents consider the different topography of hilly Jayapura and relatively plain Abepura; and $12.96 \%$ respondents opt up the history of those areas as old cities of Hollandia Haven and Hollandia Binnen. From the questionnaire, the geographical element which is the Skyline hills as the "boundary" is the most attached image perceived by the residents of Jayapura City. The opinions demonstrated the respondents' image on the distinctive visual characteristic of a space. Nevertheless, it is evidenced that geographical conditions are the most significant factor regarding with the spatial image of distinctive visual characteristic (Table 3).

Table 3. The responses of respondents on why Jayapura and Abepura seem to be two separated cities

\begin{tabular}{lcccc}
\hline $\begin{array}{c}\text { Why Jayapura and Abepura seem to be two } \\
\text { separated cities instead of a single Jayapura } \\
\text { City }\end{array}$ & $\begin{array}{c}\text { Respondents } \\
\text { of Jayapura }\end{array}$ & $\begin{array}{c}\text { Respondents of } \\
\text { Abepura }\end{array}$ & Total & $\%$ \\
\hline Separated by Skyline hills & 42 & 35 & 77 & 47.53 \\
\hline
\end{tabular}




\begin{tabular}{lcccc}
\hline $\begin{array}{l}\text { Why Jayapura and Abepura seem to be two } \\
\text { separated cities instead of a single Jayapura } \\
\text { City }\end{array}$ & $\begin{array}{c}\text { Respondents } \\
\text { of Jayapura }\end{array}$ & $\begin{array}{c}\text { Respondents of } \\
\text { Abepura }\end{array}$ & Total & $\%$ \\
\hline $\begin{array}{l}\text { Distance } \\
\begin{array}{l}\text { Only one main access road available, in } \\
\text { addition to alternative roads }\end{array}\end{array}$ & 14 & 22 & 36 & 22.22 \\
$\begin{array}{l}\text { Topography, Jayapura is hilly while Abepu- } \\
\text { ra is plains }\end{array}$ & 8 & 4 & 12 & 7.41 \\
$\begin{array}{l}\text { History of the two old cities } \\
\text { Total }\end{array}$ & 4 & 17 & 21 & 12.96 \\
\hline
\end{tabular}

Source: Research survey, 2014

The result of a survey on the image of the range of Jayapura and Abepura showed that the image is affected by geographical factors in addition to the historical image of those cities. It demonstrated by the option of "other answers" explicated by the respondents, that generally, they provided answers showing their strong impression on the spots where Jayapura and Abepura were established for the first time. Those spots are currently the centers of the cities, Jayapura at Imbi Park and Abepura at Abepura Circle.

Triangulation of data obtained from observations on the geographical conditions and the questionnaire indicated the main reason for the formation of Jayapura and Abepura was the geographic conditions of Jayapura City. They are separated by Skyline hills. It is also a crucial element of spatial structure as a unique visual characteristic perceived by most of the residents of Jayapura.

\section{Conclusion}

The spatial structure of a city is assessed from the physical and geographical conditions, as well as the visual image perceived by the residents. Geographical conditions lead to the formation of two parts of Jayapura City that are separated by Skyline Hills. Analysis of topography and land-use indicated the presence of two primary urban areas, namely, Jayapura and Abepura. This situation has caused the disconnection of those two by non-building area, thus, it seems to be unfeasible to fuse the boundaries between those areas. Historically, Jayapura and Abepura were two old cities established in the early of Jayapura City. Both of them had their own town centers constructed simultaneously during the establishment of the city. The center of Jayapura is located at Imbi Park (Taman Imbi) and Abepura is located at Abepura Circle (Lingkaran Abepura).

The results showed that the geographical conditions of Jayapura City influence on the formation of two separate urban areas, Jayapura and Abepura. The presence of two geographically separate urban areas in Jayapura City is also reinforced by the image perceived by the residents regarding with the powerful visual image of those cities. It, however, forms unique and distinctive properties in the spatial structure of Jayapura City. In its development, the existence of two urban areas show the persistent characteristics of 'two cities within a city'. As a continuation of this study, it is necessary to conduct an in-depth study on the functional linkages formed between Jayapura and Abepura in the overall system of Jayapura City.

\section{References}

Bappeda Kota Jayapura (2014). Tata Ruang Wilayah Kota Jayapura 2013-2033. Jayapura: Bappeda Kota Jayapura.

BPS Kota Jayapura (2014). Jayapura City in Figures 2014. Jayapura: BPS Kota Jayapura.

De Chiara, J. and Lee E. Koppelman (1996). Standar Perencanaan Tapak. Jakarta: Erlangga

Hartshorn, T. A. (1992). Interpreting The City: An Urban Geography. Toronto: John Wiley \& Sons.

Hartshorne, R. (1932). The Twin City District: A Unique Form of Urban Landscape. Geography Review, 431-442. 
Kambu, M.R, dkk. (2009). Satu Abad Kota Jayapura Membangun (1910-2010). Jakarta: Indomedia Global.

Kemendagri (Ministry of Home Affairs) (2013). http://www.kemendagri.go.id/pages/profildaerah/kabupaten/id/18/name/lampung/detail/1871/kota-bandar-lampung\#profil Accessed on April 20, 2013.

Kostof, S. (1992). The City Assembled: The Elements of Urban Form Through History. London: Thames \& Hudson.

Roscoe G.T. (1959). Our Neighbours in Netherlands New Guinea. Brisbane: The Jacaranda Press.

Sugiyono. (2011). Metode Penelitian Kuantitatif, Kualitatif, dan RED. Bandung: Alfabeta.

Yunus, H. S. (2010). Metode Penelitian Wilayah Kontemporer. Yogyakarta: Pustaka Pelajar. 